\title{
The Issues of Judicial Independence in Indonesia in Contemplation of Islamic Law
}

\section{Tomi Agustian, Habiburrahman, Rama Aryanda}

Instutut Agama Islam Negeri (IAIN) Curup, Indonesia tomiagustian@iaincurup.ac.id (correspondence)

\begin{abstract}
The judiciary (judicial) is an autonomous power that is unaffected by other authorities, especially the executive branch (president). However, the central to the author's analysis is the establishment of justice with the realization of an independent judicial power as the 1945 Constitution's ideals. "The judicial authority is an independent power to establish justice for the establishment of law and justice," according to Article 24 of 1945 Constitution. This principle was later codified in Article 1 Act No. 48 on the Judicial Authority, which was passed in 2009. In principle, the Supreme Court constitution states that the President's appointment of a Grand Judge is subject to congressional motion, and that the Chief, Deputy Chief, Junior Chief, and Judge of Supreme Court dismissal are also carried out by the President on Supreme Court recommendation, and this was the "loophole" which the President had that would later influence the judge's mental in decision-making. The study used normative and juridical approach to identify a link with the principle of justice in Islam, due to in Islam (either the text of the Qur'an or the Hadith) does not expressly contain the presence of Judicial Authority. The Khalifah (President) has always had the right to appoint and dismiss judges in Islamic judicial bodies. Despite the fact that the judge's appointment and dismissal were made by a Khalifah at the time, the judge remained on Allah's good side. So, when the judge's ruling in the case, it was solely aimed at achieving justice. In conclusion, the President's appointment and dismissal of a judge were obviously inappropriate because they could influence the court's conclusions, distorting the meaning of Article 24 of the 1945 Constitution and demonstrating a lack of independent justice.
\end{abstract}

Keywords: Independence; Judicial Authority; Constitution; Islamic Law. 
NEGREI : Academic Journal of Law and Govenance,

Volume 1, Number 2, 2021

\section{Introduction}

The alteration of Article 1 Section 3 of the Republic of Indonesia's 1945 Constitution that indicate that Indonesia is a state of law (Augustian. T. 2017, 103) which made Indonesia a constitutional state. After the President's decree of July 5, 1959, the state's foundation was reverted to the 1945 Constitution (Magnar 2007.10). It cannot be argued that the 1945 Constitution was founded on kinship (Sagala 2008, 33), and that it was established by People's Consultative Assembly (MPR) which completely claimed the society's sovereignty.

The MPR does not only work alone as a people's mandate in its state duties, but it also oversees five high state institutions that contribute to its performance, namely: the House of Representatives (DPR) as an institution or legislative body, the President and Vice President as an executive body, the Supreme Court as a judicial body, the Audit Board of the Republic of Indonesia (BPK) as an auditing body, and the Supreme Advisory Council (DPA) as a consultative body (Sutiyoso 2005,21). The existence of the kinship principle does not imply that each institution must cooperate in carrying out their state duties, particularly with the judiciary. (Agustian, 2016; 162)

Montesquieu proposed three shafts of power based on Locke's inspired separation of powers, which became known as the Trias Politica theory. The three powers are executive (the President and ministers administer legislation), legislative (the parliament laws), and judicial (the power of justice by the Supreme Court and the lower judicial courts and the constitutional court). Al-Maududi offered the same distribution of Montesquieu's state in three powers (executive, legislative, and judicial). As the judicial body of this society, the Supreme Court has a unique position that is unaffected by any other body. Given the enormity of the duty and responsibility that comes with delivering justice.

Every living human being comes with issues. When people ask for a legal entity to hear their case, the goal is to get justice, and each litigant party will tend to defend themselves. With the establishment of a judicial institution that is independent of other institutions "the law of the jungle" can be avoided and equality before the law-and thus justice-can be realized and even enforced. As a result, the Judicial Authority in this case is the Supreme Court and the judicial body under it, as well as the Constitutional Court, which must be noted in order to create comprehensive justice for all citizens. 


\section{Tomi Agustian, Habiburrahman, Rama Aryanda \\ The Issues of Judicial Independence in Indonesia in Contemplation of Islamic Law}

For Muslims, enforcing justice is more than just a call or a command to submit to the constitution; it is a deeper belief--that the Qur'an is the revelation of Allah. Although Islam does not explicitly state that there is a Judicial Authority in its entity as a container for the establishment of justice for the community, a commandment to uphold justice has indicated that it exists (Rosady 2000, 15). In the course of Islamic history, justice could already be found in the time of the prophet Muhammad, when he was sent to Yemen to deliver Allah's message, he acted as a judge, and thus he was the first Islamic judge (Shiddieqy 2010, 7) He also sent some friends, such as Muadz bin Jabal and Ali bin Abi Thalib to Yemen, to serve as governors and judges in various areas.

In modern terms, democracy has been trusted and gained trust as a nearly universal system, and also as a political idea that has become an ideology (Agustian, 2020, 7). It is a shared responsibility to see that justice is established. Since Indonesia has the legal power and the ability to resolve legal issues in order to create justice, then Judicial Authority must be controlled by society in order to become an independent body, free from interference from others, as the 1945 Constitution stated (Magnar 2007.10).

By formalizing or validating new regulations in order to make them valid and in effect, including changes and adjustments. In legal sense, formalization is frequently used in terms of legal adaptation to the needs of the public (Agustian. 2019, 15). In that sense, the author sees the ambiguity when it comes to the fact that the President has been authorized to appoint and dismiss the judge as arranged in Article 8 Section (1) and Article 11 Subsection (1) Act no. 5 of the 2004 Supreme Court, especially in terms of the judiciary's 2004 Article 1 Subsection (1) Act no. 42004 on the power of justice, (Act of Judicial Authority 2004, 3), which also corresponds with the 1945 Constitution Article 24 and 25, state that the Judicial Administration or Judicial Authority is independent.

The powers of justice and the Supreme Court are inseparable, as the essence of the law on the power of justice and the law on the Supreme Court should not be questioned. When the executive director, in this case the President, remains involved in the appointment and dismissal of the Grand Judge, the Chief, the Chief Deputy, the Junior Chief, and the Judge of Supreme Court, the sense of independent justice power becomes hazy. The grand ideals of the 1945 Constitution that desire a judicial body (particularly Supreme Court as the highest 
NEGREI : Academic Journal of Law and Govenance,

Volume 1, Number 2, 2021

judicial, Judicature and Contitutional Court are below it) to be completely free with no other party intervening, in order for justice to be realized for each citizen.

The independent existence of the judiciary power has continued to be a topic of conversation and debate among academics and legal observer in Indonesia. There is already a substantial body of scholarly work on the independence of the power of justice, the Supreme Court, the power of the judge, Islamic justice, and other related topics. Similarly, the author attempts to connect the theory of the Muslim thinker, Abul A'la al-Maududi, also known as Al-Maududi, who adheres to the theory that the judiciary is entirely independent or outside the executive branch (Azhar 2018, 141). The judiciary functions in carrying out Allah's laws and his ummah delegating power to Him in the name of the head of the state, so that while the ruler is the supreme leader in the state government, remains the same before the law.

In keeping with Al-Maududi's ideas, the author employed the Trias Politica theory developed by the Western thinker, Montesquieu (1689-1755). This theory is a follow-up to John Locke's power-sharing theory (English philosopher: 16321704) (Imron AM, 52, 2010)

Another scientific study that discusses the independence of the world's justice is in Mahfud MD's work, which can be found in his book "Political and Legal Struggle in Indonesia" (Mahfud MD 1999, 267-285). In this context, Mahfud MD. made significant contributions to the independent power of justice, which was also linked to the Trias Politika theory and the judicial power during the old and new orders. However, Mahfud MD was only highlighting positive law (not Islamic law), and "the book" is only in the form of a paper and thus not comprehensive. Similar with his book "Basics and Structure of Indonesian State Administration." (Mukti Arto 2018, 20)

His work also failed to highlight the standpoint of Islamic law. Furthermore, A. Mukti Arto wrote a book titled "Ideal Conception of the Supreme Court" that focuses solely on the Supreme Court (Arto 2001, 25). Mukti Arto, on the other hand, did not compile it according to Islamic law. In terms of justice in Islamic law, there are several monumental works of Islamic scholars that attempt to describe justice in Islam because, as previously stated, judicial power in Islam is an indication of judicial independence. 


\section{Tomi Agustian, Habiburrahman, Rama Aryanda \\ The Issues of Judicial Independence in Indonesia in Contemplation of Islamic Law}

Al-Mawardi, for example, launched various ideas on the judiciary (appointing judges and their requirements, jurisdiction of judges, and many other contributions) in his book Al-Abkäm as-Sultäniyyah (Nurdin 2017, 34). Salam Madkur and Hasbi ash-Shiddieqy were among the ulama' who participated in the discussion (Shiddieqy 2009, 164). Both of which convey similar ideas, namely the judiciary during the Prophet's time, the court during Al-Khulafá' ar-Räsyidūn time and the court during the dynasty. As far as the author can tell, the books, papers, and other scientific works that they have discovered are more concerned with the power of the judiciary or the freedom of judges, and thus do not directly address the author's research. This is especially true when it comes to Islamic law. As a result, there is no scientific work that focuses on it.

Based on the introduction described above, it can be stated that the main issues that will be the focus of discussion and used as material for further research are: 1) What is the status of judicial independence in Islam?, 2) How is the judiciary's independence in Indonesia?

This research is a library research, which is a study that the data sources are obtained from library, such as books and other scientific works that are relevant to the problems addressed by the author. The nature of this research is descriptive, namely by describing the power of the judiciary and the Supreme Court in Indonesia as the highest institution in the judiciary, as well as the judiciary in Islam as an indication of the existence of judicial power in Islam, based on the opinions of legal observers and Islamic law perspectives (syara'), which is then drawn with an analysis to determine the importance of the independence of Judicial Authority in Indonesia.

The author used two approaches in this study: normative and descriptive. This method is used to examine a problem using the Qur'an and Hadith to determine whether something is suitable or not, after which it is analyzed using existing norms and a legal approach. This approach is based on current regulations. The documentation method is used by the author in writing this paper, namely viewing and researching library materials related to the author's discussion, both from books, dictionaries, laws, papers, and other scientific works. Data analysis is a method for processing specific data in order to draw conclusions that are relevant to the current discussion. The author used inductive analysis method in this study, looking at the existence, position, and authority of the judiciary in 
NEGREI : Academic Journal of Law and Govenance,

Volume 1, Number 2, 2021

Indonesia, and then linking it to the legal norms that exist in Islamic judicial institutions. Next, consider the aspect of suitability.

\section{Judicial Institutional Independence in Islam and Judicial Authority Independence in Indonesia}

According to the 1945 Constitution of the Republic of Indonesia, Judicial Authority is an independent power exercised by a Supreme Court and judicial bodies under it, as well as by the Constitutional Court, to administer justice and uphold law and justice (Aritonang, and Hutasuhut, 2004, 2). Based on that, the subjects with Judicial Authority are the Supreme Court and the judicial parts under it, as well as the Constitutional Court. As a result, the independence of these bodies must be safeguarded. Separated from any institution or power, including the President or the executive. The Supreme Court, on the other hand, is the only part authorized to exercise Judicial Authority, and it includes judicial parts within the general judiciary, religious court, military court, and state administrative court (Aritonang, and Hutasuhut 2004, 10). With judicial independence, the Supreme Court and the parts under it, as well as the Constitutional Court, can decide judicial cases without relying on other parties, and justice is easier to implement.

The author emphasizes on the Supreme Court in this paper because it is the Supreme Court is the subject of Judicial Authority itself. This does not imply that the Supreme Court must be independent on its own, but rather, the Supreme Court is the highest Judicial Authority that can be used to determine the independence of the Judicial Authority subordinate to it.

\section{The Position and Authority of Indonesia's Judicial Powers}

\section{The Role of the Judiciary in Indonesia}

To understand the position of the judiciary in Indonesia, it is necessary to understand the structure of state power in Indonesia first, which is as follows: (Sutiyoso 2005, 21)

Given that the Supreme Court is the subject of Judicial Authority, it is important to understand that judicial power has the same meaning and purpose as legal power, namely the power that carries out the functions and authorities of the judiciary to enforce law and justice in the Republic of Indonesia. If observed, this description implies that the meaning of the judiciary's position is the same as the 


\section{Tomi Agustian, Habiburrahman, Rama Aryanda \\ The Issues of Judicial Independence in Indonesia in Contemplation of Islamic Law}

Supreme Court's position as a judicial body. As a result, in addition to being a high state institution, the Supreme Court is also the highest judicial institution.

In Indonesia, Supreme Court holds the same position as the other three institutions, namely the President, the House of Representatives (DPR), and the Audit Board of the Republic of Indonesia (BPK). However, the 1945 Constitution emphasizes that "Judicial Authority is an independent power to administer justice in order to uphold law and justice." The article suggests that the Judicial Authority in question is the existing judicial institutions (Supreme Court, general courts, religious courts, military courts, and state administrative courts) (Muslim Hutasuhut 2009, 7).

1) The duty of this judicial institution is to uphold the rule of law and justice.

2) Judicial Authority is an independent power.

So it cannot be denied that the Judicial Authority is a body tasked and accountable for upholding justice and the rule of law. With such a heavy burden, everything that can obstruct the realization of justice and the rule of law must be minimized. When discussing the division of state power, it is always in sync with the Trias Politica theory. However, it is important to understand that Indonesia does not follow the Trias Politica doctrine. It's just that the power conceptualized by the Trias Politica is also found in the distribution of power in Indonesia, namely (executive, legislative, and judicial), indicating that the doctrine has an impact on the power formulation in Indonesia. It is claimed that Indonesia is not a Trias Politica adherent country because, in addition to executive, legislative, and judicial powers, the Audit Board of the Republic of Indonesia (BPK) and the People's Consultative Assembly (MPR) as supremacist institutions (Mahfud MD 1999, 274-275).

Aside from the issues above, the author places a greater emphasis on the principle of Trias Politica, which is also used by Indonesia (Explanation of Articles 24 and 25 of the 1945 Constitution). The principle of an independent and impartial judiciary, in particular, as a feature and condition of the rule of law. (Ibid., 275)

\section{Reformation Era - Now}

This is a period of breaking through the government's rigidity, which has been tightly locked. Judicial Authority that cannot be separated from the ruler's or executive's grip finally collapsed with its new policy, as evidenced by the passage 
NEGREI : Academic Journal of Law and Govenance,

Volume 1, Number 2, 2021

of Law on Judicial Authority No. 4 of 2004 in conjunction with Act No. 48 of 2009, specifically concerning:

a) Article 1:

"Judicial Authority is the power of an independent state to administer justice in order to enforce law and justice based on Pancasila, for the sake of the implementation of the State of Law of the Republic."

b) Article 13:

(1) The Supreme Court has authority over the organization, administration, and finances of the Supreme Court and the judicial bodies that report to it.

(2) The Constitutional Court's organization, administration, and finances are subject to its power and authority.

(3) Provisions concerning the organization, administration, and finances of the judiciary, as referred to in Section (1), are regulated in law in accordance with the specificity of each judicial environment.

Article 13 shows that what IKAHI desired during the New Order period was realized, though the author believe this law is not enough to frame and to represent the creation of an independent institution or judiciary. Of course, further investigation is required before concluding that "the existing judiciary in Indonesia is completely independent."

It turns out that the author continues to find ambiguity, which is important when it comes to the independence of the judiciary or judicial institutions. The author is referring to the confusion that occurs when it is associated with Act No. 5 of 2004 concerning the Supreme Court. In essence, the Supreme Court is the implementing agency of the highest judicial power, which means that the Supreme Court is the pinnacle of realizing justice. So the Supreme Court and Judicial Authority are like two sides of the same coin that cannot be separated. Given their close relationship, Judicial Authority and the Supreme Court cannot adhere to a contradictory principle or provision. Such as the following articles:

a) Article 8:

(1) The President appoints the Supreme Judge from among the candidates nominated by the House of Representatives. 


\section{Tomi Agustian, Habiburrahman, Rama Aryanda \\ The Issues of Judicial Independence in Indonesia in Contemplation of Islamic Law}

(2) The House of Representatives selects the candidate for Grand Judge mentioned in paragraph (1) from the list of candidates proposed by the House of Representatives.

(3) The election of a candidate for Grand Judge, as described in paragraph (2), must take place within 14 (fourteen) days of the candidate's name being accepted by the House of Representatives.

(4) The Supreme Court's Chief and Deputy Chief are elected from and by the Grand Judge and appointed by the President.

(5) The President appoints the Junior Chief of the Supreme Court from among the Supreme Judges nominated by the Chief of the Supreme Court.

(6) The President's decision on the appointment of the Grand Judge, Chief and Chief Deputy, and Junior Chief of the Supreme Court, as referred to in paragraphs (1), (4), and (5), shall be made within 14 (fourteen) working days of the President accepting candidate submissions.

b) Article 11:

(1) The Chief, Chief Deputy, and the Judges of the Supreme Court are honorably dismissed from their positions by the president on the recommendation of the Supreme Judge of the Supreme Court because they have:

(2) passed away,

(3) reached the age of 65 (sixty-five) years,

(4) made their own request,

(5) a persistent physical or mental illness, or

(6) proven to be incompetent in carrying out their duties.

(7) If the Grand Judge reaches the age of 65 (sixty-five) years, his term can be extended to 67 (sixty-seven) years if he has exceptional work performance and is physically and mentally healthy, according to a doctor's statement. 
NEGREI : Academic Journal of Law and Govenance,

Volume 1, Number 2, 2021

According to the two articles above, it still needs to be reviewed before an independent judicial power institution can be realized, given the President's or the executive's strong and dominant intervention. In author's view, the Supreme Court's power and authority, both as a high institution and as the highest institution in the judiciary, can be applied as long as it does not conflict with the 1945 Constitution. Differences of opinion in terms of power to test laws and regulations, for example. The author agree with the legal experts' opinion in this case for the following reasons: (Mardjono 1997, 295-297)

1. The 1945 Constitution in no way prohibits or limits the judiciary's power to examine legislation. Of course, something that is not prohibited can be done.

2. It is illogical for lawmakers to limit judicial power because the 1945 Constitution states that it is a power that is free and independent in exercising its power.

3. The function of Judicial Authority is to enforce the law. The concept of constitution is broader than the definition of law. It is not impossible that legislators made mistakes when making laws (by violating legal principles), as is frequently the case.

The author adheres to the provisions that the Supreme Court's power and authority are the same, provided that they do not conflict with the provisions of the 1945 Constitution.

\section{Judicial Independence in Indonesia}

The Supreme Court, as the highest judicial institution in Indonesia, wields Judicial Authority, and the courts that report to it are as follows:

1. Religious Court,

2. Administrative Court of the State,

3. Military Court,

\section{General Court}

Because these courts are tasked with delivering justice and enforcing the rule of law in society, they must be completely independent of the intervention of other institutions, including the President. When confronted with a problem involving the executive (President), it is difficult for judges. Especially since the President 


\section{Tomi Agustian, Habiburrahman, Rama Aryanda \\ The Issues of Judicial Independence in Indonesia in Contemplation of Islamic Law}

still has a significant role in the appointment and dismissal of judges, as enshrined in Supreme Court Act No. 5 of 2004.

The provisions for the appointment and dismissal of judges are inextricably linked to the state government system that adheres to presidential aspects, such as executive power in the hands of the President and the appointment and dismissal of ministers (as assistants to the President) by the president himself (Daman 1999, 213). This means that the President has real political power in terms of running the government (Daman 1999, 212). Problems like these can have an impact on the psyche of judges when making a decision, hampered the realization of independent judicial power.

Looking at the evolution of judicial power during these periods, it is clear that the results of the amendments to Act No. 4 of 2004 on the previous law have not achieved what the 1945 Constitution aspires to, particularly the explanation of Articles 24 and 25, which concern the independence of Judicial Authority in Indonesia. As a result, it is necessary to conduct a review in order for the Judicial Authority to be truly independent and free of any interference. The independence of the judiciary does not imply that the judiciary's power is unrestricted, because it is also intended to prevent abuse of power by those in power.

On the other hand, while the author refers to the powers and authorities of the judiciary in Indonesia the meaning is the power and authority of the Supreme Court as the highest judicial institution and the highest institution in Indonesia. The Supreme Court's power is an independent power, so intervention from any party is not justified, and anything that can influence judges' decisions must be eliminated. Similarly, the President is in charge of the system for appointing Supreme Court Justices as well as dismissing the Chief, Deputy Chief, and the Judges of the Supreme Court. This is contrary to the spirit of the 1945 Constitution, particularly the explanations of Articles 24 and 25, which state explicitly that Judicial Authority is an independent power free of the influence of other institutions. Whereas the President's appointment and dismissal of a judge will almost certainly limit a judge's power and authority. The nature of the ewnh pekewn (obstacles), as well as all the feelings that the President "gave birth" to him as a judge, will always be lodged and have a significant impact on the judge's psyche. As a result, when confronted with a problem that involves the President, a judge's firmness in deciding case is shaken. 
NEGREI : Academic Journal of Law and Govenance,

Volume 1, Number 2, 2021

This is clearly not in accordance with sharia's principles of justice. As Allah expresses it:

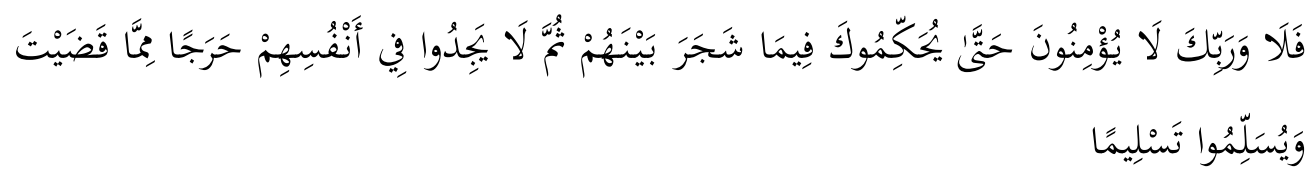

Previously, during the time of Rasulullah, the Khalifab had the authority to appoint and dismiss judges, but this had no effect on the judge's mental in deciding matters. Because the judges had a strong fear of God at the time. (An-Nisa, (4) 65) Looking at the culture that is emerging in the midst of Indonesian society today, the application of the President's appointment and dismissal of a judge, as was done in the early days of Islamic justice, is clearly inappropriate.

As a result, all powers and authorities vested in the Supreme Court may be exercised so long as they promote the realization of justice, which is also consistent with the spirit of the 1945 Constitution. Given the current state of affairs in Indonesia, Article 8 Section (1) and Article 11 Section (1) of Act No. 5 of 2004 concerning the Supreme Court should be reconsidered for the sake of the common good (enforcement of law and justice).

\section{An Examination of Judicial Independence in Indonesia from the Perspective of Islamic Law}

The independence of the judiciary or Judicial Authority, as idealized in the 1945 Constitution, particularly in Article 24, is a universal and noble principle that must be fought for. The independence of judges in Indonesia is guaranteed by the constitution, but the constitutional provisions and laws that guarantee the independence of the judiciary in their application are very likely to be influenced by other powers or institutions.

According to Bambang Sutiyoso and Sri Hastuti Puspitasari, many parameters can be used to assess a judicial institution's independence, including: (Bambang Sutiyoso and Hastuti Puspitasari 2005, 52)

1. The judiciary's independence

The judiciary's independence can be seen in several ways, including the institution's lack of reliance on other institutions. If the integrity and independence of a judicial institution can be affected, it means that the institution 


\section{Tomi Agustian, Habiburrahman, Rama Aryanda \\ The Issues of Judicial Independence in Indonesia in Contemplation of Islamic Law}

is or is not independent. Furthermore, if the judicial institution has a formal upward hierarchical relationship and the superior institution has the ability to intervene, this indicates that the judiciary is not or lacks independence.

2. An impartial judicial system

If there is no to little interference from other institutions during the case examination process, evidence, and decision-making process, but it does not affect the outcome of the decision, the judicial process is independent. If, on the other hand, other institutions intervene and the judiciary is influenced in making decisions, it indicates that the judicial process is not or is only partially independent.

\section{A judge's independence}

If a judge's decision is not influenced by mental pressure or intervention from other institutions, it indicates that the judge is independent in making the decision. However, if the judge is influenced, it indicates that the judge is less or even not independent.

To the author's view, any issues that may have an impact on the judicial process or judicial institutions, as well as issues that may have an impact on judges must be minimized. Like the President's system of appointing and dismissing judges.

The principle of judicial independence is very relevant to Islamic law principles, which are both aimed at achieving justice for the entire ummah.

\section{Conclusion}

Several conclusions can be drawn based on the preceding description, particularly regarding the Judicial Authority and the Supreme Court which is compiled with the judiciary in Islam:

Although Allah's revelation (Al-Qur'an) does not explicitly explain the existence of judicial power in Islam, the history of Islamic courts proves that since the sending of the Prophet as the Khalifah as well as qädi (Judge) in the history of Islamic courts, it is an indication of the existence of Judicial Authority in Islam. Furthermore, the government at the time was sufficient to demonstrate the existence of an independent judiciary, because the Rasulullah entrusted his people's decisions to the judges he appointed. Although the Khalifah or the executive had the authority to appoint and dismiss judges in the beginning, this 
NEGREI : Academic Journal of Law and Govenance,

Volume 1, Number 2, 2021

does not mean that it can be applied in Indonesia in an economic, social, and cultural era that is vastly different from that time. A judge had a high fear of Allah at the time, so the appointment of a judge by the Khalifah was not an impediment to upholding truly fair and impartial justice, even when confronted with the Khalifah who had appointed him as a judge. Especially when one considers the socio-cultural conditions that are emerging in Indonesia, such as the nature of the work corps (obedient to superiors) and the rules that are already thicken and ingrained in every citizen (especially in the judges' persona;).

Judicial Authority is independent from other institutions, including the executive (president). The judiciary's independence is a critical requirement for achieving a truly fair and impartial judiciary. As a result, this institution must not be bound by other institutions, both structurally and functionally, in order to avoid the influence and intervention of these institutions. This means that the executive or president's appointment and dismissal of a judge is clearly not in accordance with the ideals of the 1945 Constitution, particularly the explanation of Articles 24 and 25. The independence of Judicial Authority is primarily concerned with upholding the law and achieving justice. Furthermore, the judiciary's independence is intended to limit the president's power so that he does not act despotically (arbitrarily).

\section{Bibliography}

Agustian, T. (2017). "Implikasi Terhadap Pengujian Ketetapan MPR/MPRS Pasca Putusan Mahkamah Konstitusi Dalam Rangka Mengawal Tegaknya Konstitusi Negara”. University Of Bengkulu Law Journal, 2(2), 103-122.

Agustian, T. (2019). "Formalisasi Hukum Islam Kedalam Tata Hukum Indonesia". El-Ghiroh: Jurnal Studi Keislaman, 16(01), 15-36.

Agustian, T. (2016). "Implikasi Pengujian Ketetapan MPR dalam Sistem Ketatanegaraan Republik Indonesia Pasca Putusan Mahkamah Konstitusi No. 75/PUU-XII/2014”. Lex Renaissance, 1(1), 1.

Agustian, T. (2016). “Analisis Putusan Mahkamah Konstitusi Nomor 86/PUUXI/2013 dan Nomor 75/PUU-XII/2014 Tentang Judicial Review Ketetapan MPR/MPRS Pasca Lahirnya Undang-Undang Nomor 12 Tahun 2011” (Doctoral dissertation).

Agustian, T. (2020). "Demokrasi Islam dalam Pandangan Muhammad Natsir dan Muhammad Abid Al-Jabiri”. El-Ghiroh: Jurnal Studi Keislaman, 18(01), 7 24. 


\section{Tomi Agustian, Habiburrahman, Rama Aryanda \\ The Issues of Judicial Independence in Indonesia in Contemplation of Islamic Law}

Aritonang, 2004 , Undang-Undang Kekuasaan Kekuasaan Kehakiman, Jakarta: Pustaka Pergaulan.

Arto, A. Mukti. 2001. Konsepsi Ideal Mabkamah Agung, Yogyakarta: Pustaka Pelajar.

Azhar, Muh .2018. Filsafat Politik Perbandingan Antara Islam dan Barat, Jakarta: PT. Raja Grafindo Persada.

Bagir Manan dan Kuntana Magnar, Beberapa Masalah, Pasal 24 dan 25 UUD 1945.

Daman, Rozikin .1993, Hukum, Jakarta: Raja Grafindo Persada.

Imam al-Mawardi, 2000. al-Abkäm as-sultaniyyah wa al-wilāyatu ad-diniyyah, translated by Abdul Hayyie al-Kattani and Kamaluddin Nurdin, Jakarta: Gema Insani Press.

M. Salam Madkur,1982 al-Qadā fì al-Isläm, translated by Imron AM, Surabaya: PT. Bina Ilmu,.

Mahfud MD. Moh, 1999. Pergulatan Politik dan Hukum di Indonesia, Yogyakarta: Gama Media.

Mardjono, Harton. 1997 Menegakkan Syari'at Islam dalam Konteks Keindonesiaan, Bandung: Mizan.

Rosady, Imron, 2009, "Tinjauan Hukum Islam Terhadap Independensi kekuasaan kehakiman Dalam UU No 5 tahun 2004", Yogyakarta, UIN Suka.

Shiddieqy, 2001. Peradilan dan Hukum Acara Islam, Semarang: PT.Putaka Rizki utera,

Shiddieqy, Hasbi ash. 1999. Sejarah Peradilan Islam, Djakarta: Bulan Bintang,.

Sutiyoso, 2005, Aspek-aspek Perkembangan Kekuasaan Kehakiman di Indonesia, Yogyakarta: UII Press.

Wahyudi, 1999. "Tinjauan Hukum Islam Terhadap Kebebasan Hakim (Studi Atas Pasal 1 ayat (1) dan Pasal 14 (1) Undang-Undang No. 35 Tahun 1999 Tentang Ketentuan Pokok Kekuasaan Kehakiman)," Skripsi, Fakultas Syari'ah, Peradilan Agama, IAIN Sunan Kalijaga, Yogyakarta,

Undang-Undang Kekuasaan Kehakiman, ( Jakarta: Pustaka Pergaulan, 2004), hlm. 3 .

An-Nisa (4): 65. 